\title{
Development of a model of HTLV-1 oral transmission in the rabbit
}

\author{
Robyn Haines ${ }^{1}$, Rebeccah Urbiztondo ${ }^{1}$, Rashade Haynes ${ }^{1}$, Stefan Niewiesk ${ }^{1}$, Michael Lairmore ${ }^{2,3^{*}}$ \\ From 15th International Conference on Human Retroviruses: HTLV and Related Viruses \\ Leuven and Gembloux, Belgium. 5-8 June 2011
}

A primary route of transmission of human T-lymphotropic virus 1 (HTLV-1) is from mother-to-child via breast milk, but knowledge of the early immunologic events in orally acquired HTLV-1 infection is limited. Herein, we characterized normal rabbit gut-associated lymphoid tissues (GALT) and performed studies to develop an oral model of HTLV-1 infection. Mononuclear leukocytes were immunophenotyped from key GALT inductive and effector sites using flow cytometry and immunohistochemistry. Our data indicate that unexposed rabbits GALT have a predominant CD4+ lymphocyte population similar to humans. To establish a HTLV-1 oral model 12 week old female New Zealand White rabbits were orally or intravenously inoculated with $\mathrm{CD} 3+\mathrm{CD} 4+\mathrm{CD} 25+$ rabbit lymphocyte cell line immortalized with the HTLV-1 molecular clone ACH (R-49 cells) or control Jurkat T-cells orally. The rabbits were monitored for hematologic and virologic parameters prior to serial sacrifice. Collectively, 66 to $100 \%$ of HTLV-1 orally exposed rabbits became persistently infected. HTLV-1orally exposed and infected rabbits during early time points (1-4 weeks post exposure) had delayed and often less intense anti-HTLV-1 antibody response, variable leukocytosis, and a delayed p19 matrix antigen production and proviral DNA amounts in peripheral blood leukocytes compared to IV exposed rabbits. Interestingly, by 8 weeks post exposure orally exposed rabbits had established similar systemic spread of the virus compared to IV exposed rabbits. This oral model of HTLV-1 transmission in rabbits creates to opportunity to test the role of the mucosal microenvironment during the early stages of orally-acquired HTLV-1 in gut-associated lymphoid tissue.

\footnotetext{
* Correspondence: lairmore.1@osu.edu

${ }^{2}$ Department of Veterinary Biosciences, Center for Retrovirus Research, The

Ohio State University, Columbus, Ohio, 43210, USA

Full list of author information is available at the end of the article
}

\section{Author details}

'Department of Veterinary Biosciences, The Ohio State University, Columbus, Ohio, 43210, USA. ²Department of Veterinary Biosciences, Center for Retrovirus Research, The Ohio State University, Columbus, Ohio, 43210, USA. ${ }^{3}$ Comprehensive Cancer Center, Arthur G. James Cancer Hospital and Solove Research Institute, The Ohio State University, Columbus, Ohio, 43210, USA.

Published: 6 June 2011

doi:10.1186/1742-4690-8-S1-A19

Cite this article as: Haines et al:: Development of a model of HTLV-1 oral transmission in the rabbit. Retrovirology 2011 8(Suppl 1):A19.

\section{Submit your next manuscript to BioMed Central and take full advantage of: \\ - Convenient online submission \\ - Thorough peer review \\ - No space constraints or color figure charges \\ - Immediate publication on acceptance \\ - Inclusion in PubMed, CAS, Scopus and Google Scholar \\ - Research which is freely available for redistribution \\ Submit your manuscript at www.biomedcentral.com/submit}

C Biomed Central

() 2011 Haines et al; licensee BioMed Central Ltd. This is an open access article distributed under the terms of the Creative Commons Attribution License (http://creativecommons.org/licenses/by/2.0), which permits unrestricted use, distribution, and reproduction in any medium, provided the original work is properly cited. 